\title{
Etnicidade e saúde da população negra no Brasil
}

Na década de 80, o movimento de mulheres negras tornou visível os problemas relativos à vida sexual e reprodutiva que atingem especificamente as mulheres negras no Brasil. Juntamente com o movimento negro, demonstrou a exclusão dos direitos e cidadania da população negra no país, afirmando que os negros são pobres sobretudo porque são negros.

As desigualdades sociais vivenciadas por essa população são expressas em seus corpos e na qualidade e quantidade de serviços sociais públicos a que têm acesso. Tais constatações corroboram a idéia de desigualdade social, presente nas produções teóricas e intervenções políticas neste campo, catalisam e sistematizam as reivindicações da população negra na área da saúde, publicizando essa especificidade nas esferas nacional e internacional.

De acordo com essa visão, Roland (Cadernos Geledés, v. 1, 1991) coloca que a percepção das desigualdades raciais no tocante à saúde no Brasil é ainda muito incipiente. Nesse contexto de discussão, novos atores apresentam-se na cena social para apontar a necessidade de dados sobre a situação de saúde da população negra. A produção de informação passou então a ser um forte componente para a construção e fortalecimento da identidade negra. Esse novo sujeito político entendeu que o "quesito cor" ou a identificação racial é um item necessário e indispensável nos serviços de saúde, não apenas por facilitar o diagnóstico e prevenção de doenças atualmente consideradas étnicas mas, sobretudo, pela possibilidade de saber do que adoece e do que morre a população negra no Brasil.

A importância do quesito cor no Sistema de Informação de Saúde deve-se, então, à constatação de que, apesar de a população auto-declarada afro-descendente representar $44 \%$ da população brasileira, segundo dados censitários, poucas informações sobre seu bem-estar e saúde pode ser reunida. É interessante ressaltar que, tendo em vista uma compreensão que não estabelece uma relação de causalidade entre o quesito cor e o surgimento de doenças, essa informação, acredita-se, pode dar significativas indicações sobre as condições de vida e saúde da população negra.

A importância do quesito cor tem sido, a despeito das dificuldades de coleta, uma reivindicação do movimento negro, para que se possa conhecer melhor os aspetos de vida e saúde da população negra, além de exigir o reconhecimento social e político desta parcela da população.

Foi nesse contexto de reivindicação social e política que, durante o período da administração de Luiza Erundina na Prefeitura de São Paulo, o quesito cor foi implantado, por meio da Portaria 696/90, e permitiu conhecer a morbimortalidade da população negra nessa cidade. No entanto, a partir de 1993, essa proposta foi praticamente extinta no governo de Paulo Maluf. Outras prefeituras de cidades brasileiras implementaram esse tipo de serviço, a exemplo de Belo Horizonte. Além disso, através do Programa Nacional de Direitos Humanos, em 1996 a Presidência da República propôs a inclusão do quesito cor como uma ação de curto prazo, além de apoio às ações desenvolvidas por seu Grupo Interministerial para a Valorização da População Negra. O renascimento dessa proposta, sob a forma de Projeto de Lei de autoria de Carlos Neder, ainda em tramitação na Câmara Municipal de São Paulo, mostra a permanência do desejo do Movimento Negro em ver o "Quesito Cor" implementado no Sistema de Informação de Saúde.

\section{Elizabete Aparecida Pinto}

Fala Preta! Organização de Mulheres Negras, São Paulo, Brasil

lizpinto@uol.com.br

Raquel Souzas

Fala Preta! Organização de Mulheres Negras, São Paulo, Brasil raquelsouzas@hotmail.com 


\section{Ethnicity and health in the Black Brazilian population}

During the 1980s, the Black Brazilian women's movement raised the visibility of problems related to sexuality and reproduction specifically affecting African-descendant women. Together with the Black movement as a whole, the Black women's movement demonstrated how the country's African-descendant population is excluded from its rights and citizenship, affirming that Blacks are poor primarily because they are Black.

The social inequalities experienced by African-descendant Brazilians are expressed in their bodies and in the quality and quantity of public social services accessed by them. These observations corroborate the concept of social inequality underlying the academic research and policies in this area, catalyzing and systematizing the Black population's health demands and raising the issue's visibility at the national and international levels.

According to Roland (Cadernos Geledés, v.1, 1991), the perception of health-related racial inequalities in Brazil is still incipient. New actors are appearing on the social scene to highlight the need for data on the Black population's health situation. The production of information has thus become a key factor for building and strengthening Black identity. These new political stakeholders have realized that the "color item" or racial identification is necessary (indeed indispensable) information for health services, not only to aid in the diagnosis and prevention of what are currently considered ethnic diseases, but above all to help understand morbidity and mortality patterns in the country's Black population.

The color item is thus relevant to the National Health Information System because although self-declared African-descendants represent $44 \%$ of the total Brazilian population according to official census data, little information is available on their health and well-being. Although there is no proven causal relationship between color and disease, it is believed that this information may provide significant indications as to the health and living conditions of the Black population.

Despite difficulties in collecting such information, incorporation of the color item has become a demand on the part of the Black movement in order to elucidate health and living conditions in the African-descendant population, besides bolstering demands for the social and political recognition of African-Brazilians.

In this context of social and political redress, during the administration of Luiza Erundina as Mayor of São Paulo, the color item was incorporated into health records under the terms of Ruling 696/90 and contributed to greater knowledge of morbidity and mortality in the city's Black population. However, in 1993 this same proposal was virtually revoked by the Paulo Maluf Administration. Other municipal governments in Brazil, like Belo Horizonte, also incorporated information on color in health records. In addition, through the National Human Rights Program, the Executive Branch proposed to incorporate the color item in the short term in addition to supporting measures by its Inter-Ministerial Group for Promotion of the Black Population. The rebirth of this proposal in the form of a bill submitted by Carlos Neder, currently under review in the São Paulo City Council, proves that the Black movement has kept its demand alive to see data on color included in the National Health Information System.

Elizabete Aparecida Pinto

Fala Preta! Organização de Mulheres Negras, São Paulo, Brasil

lizpinto@uol.com.br

Raquel Souzas

Fala Preta! Organização de Mulheres Negras, São Paulo, Brasil

raquelsouzas@hotmail.com 